\title{
Rocky start for new biology building on Californian campus
}

Berkeley

THE problems plaguing the new Life Sciences Building Addition (LSA) on the Berkeley campus of the University of California are either unusually serious consequences of poor design and construction or just the normal fine-tuning that a new building must experience.

In a classic case of where-you-standdepends-on-where-you-sit, those happily settled in the new building, with money for necessary retrofits, say the problems have been exaggerated. But those who have been forced to wait more than a year to move in tell horror stories of the causes that have delayed their occupancy.

The LSA is part of a large buildingprogramme now under way at Berkeley. A second new biology building is nearing completion, and work will begin shortly on a complete remodelling of the venerable Life Sciences Building. All this coincides with a reorganization of graduate biology education at Berkeley (see

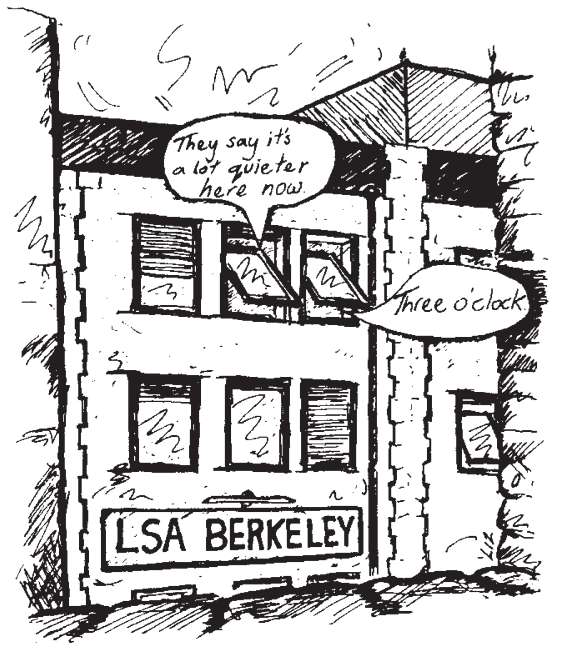

Nature 329, 575; 1987). The LSA was due to have opened last year, but construction delays pushed that date back to January.

According to Gunther Stent, who will chair the new department of molecular and cellular biology, no scientists were allowed inside the building until an opening cocktail party in January. Many of those who then toured the building were appalled by what they found.

Noise was the most noticeable problem, occasioned by the volume of air pumped through the ventilation system to yield 12 air exchanges an hour. The problem is evidently exacerbated by turbulence; air streams make right-angled bends as they pass through ventilation ducts.

Other problems have also come to light. Some shelving was mounted upside-down. air was drawn into fume hoods at such a velocity as to make them virtually un- usable and drains in the animal care facilities had obviously been sited at the high points of sloping floors.

But the worst problem was noise. John Miller, a neurobiologist working on cerci, a sensory organ of crickets, says that even with damping, the vibration caused by the air rushing through the ventilation system will force him to abandon his research model unless extensive changes are made. Even for those whose research is not hindered by it, the noise has made some reluctant to move into the building.

But researchers who have moved in say the building is working out just fine. Biochemistry professor Gerald Rubin acknowledges that there have been some problems, but says that minor adjustments have cleared them up. Louise Taylor, special assistant to the vice- chancellor who is responsible for the LSA, says the building's problems were merely routine, and that people have been clamouring to use the building.

Taylor says occupancy is now 42 per cent, and growing. She maintains that the "air exchange problem is not an issue", and that noise problems that seem severe in an empty laboratory disappear when people and equipment are moved in. She adds that Stent, one of the first to complain about the noise, may have had an exaggerated perception of the problem because he wears a hearing aid.

Although the new building has inflamed passions among the Berkeley biology faculty, most agree that the problems are on their way to being solved. An engineer hired to oversee retrofit efforts earlier this summer has evidently found cost-effective ways of solving many of the problems, and even the building's severest critics feel the worst is over. Says Miller, "Ultimately it's going to be a great place to be - when it's fixed."
Joseph Palca

\section{British charity deal with Japan on anti-cancer drug technology}

Tokyo

THE flow of British drug technology to Japan may increase substantially with the signing last week of an agreement between Sumitomo Corporation and the commercial arm of Cancer Research Campaign (CRC), a charity which funds much of Britain's cancer research.

Under the agreement with CRC Technology Ltd, the wholly owned company of the campaign, Sumitomo will act as sole agent in Japan to license inventions and drugs arising out of CRC-funded research. Sumitomo made a similar arrangement with Britain's Medical Research Council in July (Nature 334, 3; 1988); the two agreements offer Japanese corporations the opportunity to develop the inventions of a large sector of Britain's medical research community. Hitherto, Japanese pharmaceutical and chemical companies have relied heavily on the United States as a source of new inventions in the medical field.

CRC, with an annual budget of about $£ 30$ million derived from donations and legacies, supports four major cancer research centres in Britain (the Institute for Cancer Research, the Beaston Institute of Cancer Research, the Gray Laboratory and the Paterson Institute for Cancer Research), provides grants to over 60 university medical departments, and also supports two centres for clinical trials of new anti-cancer drugs

CRC Technology Ltd was established in 1982 to transfer technology developed through CRC-funded research to the private sector. Formerly called Carlton
Medical Products Ltd, the company was revamped and renamed last year in line with government policy to strengthen links between industry and universities.

$\mathrm{CRC}$ plays a leading role in developing and testing new anti-cancer drugs in Europe and North America. But, according to Sue Foden, Managing Director of CRC Technology, no CRC drugs or technology have been developed or tested in Japan. She foresees many opportunities here, particularly for drugs to treat cancers, such as stomach cancer, that are common in Britain and Japan. And she hopes that the agreement will lead to a "large flow of money" back to Britain to support further campaign research. Foden says it was recently agreed that the cam. paign will hold the patent rights to campaign-funded research but profits from licensing will be shared equally with the British research organizations where the inventions are made.

Takao Hirose of the New Drug and Biochemical Development Department at Sumitomo says "many" Japanese pharmaceutical and chemical companies are interested in developing British anticancer drugs. Japan's anti-cancer drug market is one of the world's largest but at present it is dominated by drugs of questionable efficacy. Many Japanese doctors seem to select anti-cancer drugs for their lack of side effects rather than efficacy because such drugs can be prescribed in large quantities for large profit, according to Dr Jonathan P. Bolton, an analyst at Schroder Investment Management (Japan) Ltd.
David Swinbanks 